
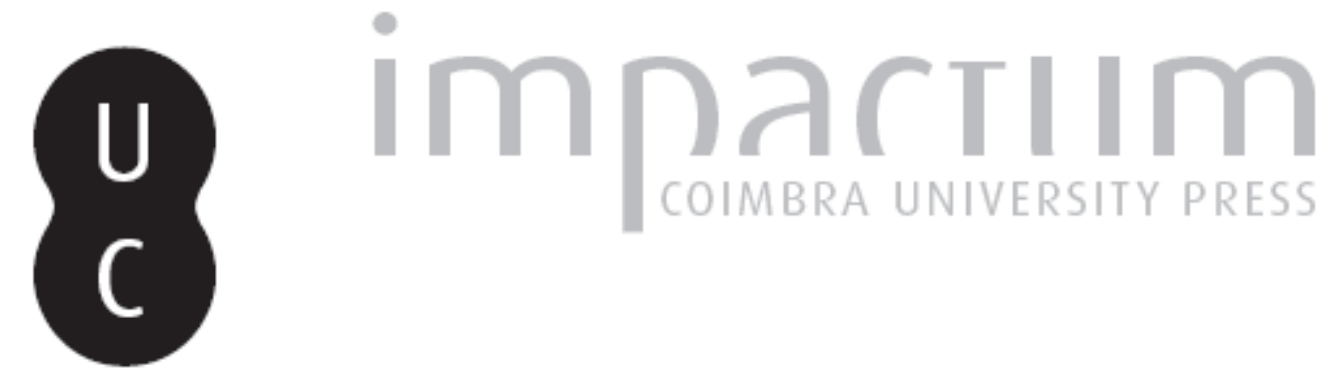

Does the EU Regional Policy reinforce the European citizenship?

Autor(es): $\quad$ Courcelle, Thibault; Taulelle, François

Publicado por: Centro de Informação Europe Direct de Aveiro; Centro de Estudos

Interdisciplinares do Século XX

URL

persistente:

URI:http://hdl.handle.net/10316.2/37114

DOI:

DOI:http://dx.doi.org/10.14195/1647-6336_12_9

Accessed : $\quad$ 26-Apr-2023 08:56:51

A navegação consulta e descarregamento dos títulos inseridos nas Bibliotecas Digitais UC Digitalis, UC Pombalina e UC Impactum, pressupõem a aceitação plena e sem reservas dos Termos e Condições de Uso destas Bibliotecas Digitais, disponíveis em https://digitalis.uc.pt/pt-pt/termos.

Conforme exposto nos referidos Termos e Condições de Uso, o descarregamento de títulos de acesso restrito requer uma licença válida de autorização devendo o utilizador aceder ao(s) documento(s) a partir de um endereço de IP da instituição detentora da supramencionada licença.

Ao utilizador é apenas permitido o descarregamento para uso pessoal, pelo que o emprego do(s) título(s) descarregado(s) para outro fim, designadamente comercial, carece de autorização do respetivo autor ou editor da obra.

Na medida em que todas as obras da UC Digitalis se encontram protegidas pelo Código do Direito de Autor e Direitos Conexos e demais legislação aplicável, toda a cópia, parcial ou total, deste documento, nos casos em que é legalmente admitida, deverá conter ou fazer-se acompanhar por este aviso.

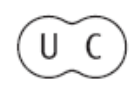


DEBATER

A EUROPA

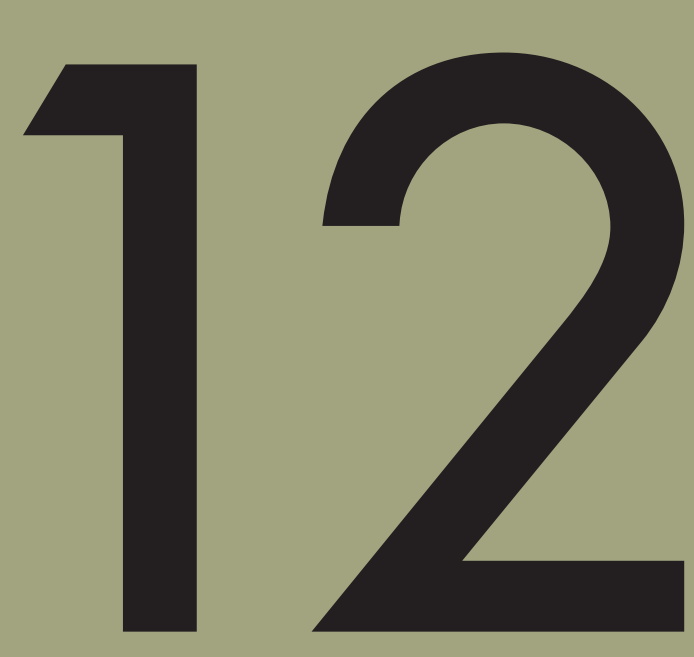

jan-jun 2015

POLITICAS REGIONAIS DA UE

EU REGIONAL POLICIES 
DEBATER A EUROPA

Periódico do CIEDA e do CEIS20, em parceria com GPE e a RCE.

N.12 janeiro/junho 2015 - Semestral

ISSN 1647-6336

Disponível em: http://www.europe-direct-aveiro.aeva.eu/debatereuropa/

\title{
Does the EU Regional Policy reinforce the European citizenship?
}

\author{
Thibault Courcelle \\ Full Professor, Université de Toulouse \\ Centre interdisciplinaire d'études urbaines (CIEU) \\ E-mail : thibault.courcelle@univ-jfc.fr \\ François Taulelle \\ Associate Professor, Université de Toulouse \\ Centre interdisciplinaire d'études urbaines (CIEU) \\ E-mail : francois.taulelle@univ-jfc.fr
}

\begin{abstract}
The European institutions are often described as distant, inaccessible and understandable to citizens. The EU Regional Policies, which starts at the local and regional level, however, shows that Europe is also a concrete construction. The files for EU funds, although it is often tedious, requires local and regional authorities to adopt a proactive and conscious approach and opt for an approach based on cooperation and partnership. Many politicians therefore consider that cohesion policy has helped to bring Europe closer to the citizens, giving the European project a more palpable face. We try in this paper to define what is European citizenship meant and to measure the impact of the EU Regional Policies to European citizens.
\end{abstract}

Keywords: EU Regional Policy; European citizenship; Europe 


\section{Foreword}

Cohesion Policy - also termed European Regional Policy (ERP) - is one of the major EU policies, representing alongside the CAP the main expenditure item, or 32,5\% of EU expenses ${ }^{1}$ over the 2014-2020 period.

Such policy should appeal to European citizens as it is aimed at financing development projects or initiatives in favour of individuals (professional training, «social inclusion»). Its objective is to foster solidarity among infra-national territories in order to reduce development gaps, which in the language of the EU translates as "cohesion". This is affirmed in article 174 of the Lisbon Treaty ${ }^{2}$ which was adopted in 2007:

«In order to promote its overall harmonious development, the Union shall develop and pursue its actions leading to the strengthening of its economic, social and territorial cohesion.

In particular, the Union shall aim at reducing disparities between the levels of development of the various regions and the backwardness of the least favored regions.

Among the regions concerned, particular attention shall be paid to rural areas, areas affected by industrial transition, and regions which suffer from severe and permanent natural or demographic handicaps such as the northernmost regions with very low population density and island, crossborder and mountain regions.»

This is therefore a very ambitious policy aimed at achieving a union of European States through progressive social and territorial harmonisation. All citizens are made aware of this policy as the European Union has provided for mandatory disclosure by beneficiaries, following a very precise reference system. Lastly, such policy can only work through the implementation of projects and thus requires effective mobilisation at the local level: the notion of eligibility entails that a given territory may be granted financing only if projects exist and if on that basis a request for financing has been duly submitted.

It is the view of former European Commission president Jacques Delors, and also that of many policymakers, that Cohesion Policy greatly enhances the concept of European citizenship. In the course of an interview for the European Commission magazine Panorama ${ }^{3}$, he claimed:

\footnotetext{
${ }^{1}$ European Commission website : http://ec.europa.eu/regional_policy/thefunds/funding/data/graphics/cohesionpolicy20142020_full_highres.png

${ }^{2}$ Traité de Lisbonne : http://europa.eu/pol/pdf/qc3209190frc_002.pdf, p. 128.

${ }^{3}$ Interview with Panorama magazine, n43, autumn 2012, p. 6.
} 
"Cohesion Policy is a way of making the European project more accessible to European citizens and to palliate the shortfalls of democracy. The thousands of projects being financed by way of Cohesion Policy show ordinary citizens that Europe is working for them." Similarly Gérard Onesta, former vice-President of the European Parliament and currently vice-President of the Région Midi-Pyrénées, whom the authors met in the course of an interview ${ }^{4}$, pointed out that he held this policy to be "the most integrationist in the Union and the best geared to address wealth redistribution".

Yet, despite the numerous projects being financed in member countries under Europe's auspicious banner, the general public knows precious little about Cohesion Policy. It is hardly ever mentioned in the media or in public debates, when compared with the CAP which has a similar budget structure. The question raised in the present paper is whether Cohesion Policy can be instrumental in building European citizenship. We intend to show what leverage it has, and what its limitations are. We will also show that such limitations do not originate in the nature of the public policy itself, but to a much larger extent in the nature of the European project.

\section{I - Cohesion Policy as a tool for building European citizenship.}

At the time the Treaty of Rome was signed, development gaps were plain to see among the various regions of EEC member countries. So it was that in Italy, the plebiscited work by Carlo Levi, Christ stopped at Eboli, a representation of a hopelessly declining Mezzogiorno, or that of Jean-François Gravier, Paris and the French Desert, lay the geographical foundations, in Italy and in France, for future urban planning policies. However, heads of State and government leaders were devoting their energies to creating an internal market and, even though such gaps were mentioned in the preamble to the Treaty ${ }^{5}$, they failed to define any specific actions aimed at correcting territorial imbalances. They hoped that the border-free internal market would eventually prove to be a powerful tool for integration, verifying the theories of such economists as Adam Smith or David Ricardo. Yet disparities deepened, initially with the crisis of 1973, which exposed the sharp decline affecting industrial territories (Nord-Pas-de-Calais, the

\footnotetext{
${ }^{4}$ Interview with Gérard Onesta on 6 December 2013 at the Conseil Régional de Midi-Pyrénées.

${ }^{5}$ It is stated in the preamble to the Treaty of Rome that the chiefs of State and of government of the six founding States were "Committed to reinforcing the unity of their economies and to ensure their harmonious development by reducing the gaps among regions and the backwardness of the least favoured of them."
} 
industrial regions of the United Kingdom, etc.) then with the adhesion of new countries such as Greece in 1981 and Spain and Portugal in 1986. These countries had significant regional gaps and the EEC contemplated stepping in to correct imbalances. As early as 1975, and paradoxically under the impulse of the least europeist state, the United Kingdom ${ }^{6}$, the EEC set up the European Regional Development Fund (ERDF). This was not, however, constitutive of a truly corrective and interventionist policy. Not until the implementation of Regional Policy in 1989, upon the initiative of Jacques Delors, did such instrument acquire financial clout and display its ambition accordingly ${ }^{7}$. The 2014-2020 Cohesion Policy programme period for twelve member States was 351,8 billion euros, a leap from the 69 billion ECU allocated to the first 1988-1993 programme period. Such increase, sharp as it may seem, needs to be put into perspective as within the said period of time the EU was joined by fifteen new members, including some ten Central or Eastern Europe States which reinforced disparities in socio-economic development among its members.

The primary goal of Regional Policy resides in economic and social convergence to achieve homogeneous development across European territories. The use of the term convergence is misleading with regard to the aim mentioned in the previous statement. In truth, the notion of economic convergence applies to the convergence of economies, which evokes a macroeconomic approach based on adjusting GDPs. Where Regional Policy is concerned, the aim is economic and social cohesion. There is a major difference. In 2007 Le Monde ran the following headline about Ireland: "The newly-prosperous Ireland still displays the infrastructure of a poor state" The article went on: "schools, transportation, and health: lagging public services are yet to be overhauled despite the Irish economic boom". The said article makes plain the discrepancy existing between a convergence of GDP, exemplified in this case by the Irish model during the course of the 1990s, and a projected cohesion scheme of a more qualitative nature, one which, unlike GDP standardisation, may take into account such elements as personal welfare and the improvement of living conditions. Regional Policy is consistently hindered by the dual approach involving both cohesion and convergence. Thus, the sole yardstick for measuring the development gaps on which the rating of European regions relies is regional GDP, when the primary objective of that policy is to build cohesion among European citizens. Interestingly

\footnotetext{
${ }^{6}$ The United Kingdom, as a new member since 1973, seldom signed up for the CAP and demanded fair return for their contribution to the European budget. The FEDER (T.N. European Regional Development fund) brought assistance to economically challenged British mining and industrial regions.

${ }^{7}$ See DREVET J.-F. - Histoire de la politique régionale de l'Union européenne. Paris : Belin, 2008, 285 p.

${ }^{8}$ Marion Van Renterguem, Le Monde, 21 septembre 2007.
} 
enough, the EU is now using the term "inclusive growth" in an attempt to combine twin objectives of a different nature?

The final assessment of Regional Policy is to be strongly mitigated even though the financial means allocated since the late 1980s have profoundly transformed the regions that were granted such support.

Firstly, the States in which Regional Policy is implemented are welfare states with redistribution policies already in place. Therefore, within a pooled budget representing a mere $1 \%$ of the GDP of European States, the financial volume allocated to Cohesion Policy remains very modest. Gérard Onesta pointed out that, for a country such as France, it represents around " $20 \%$ of the money injected into a given territory". This may constitute a significant commitment to solidarity at a national level, yet not significant enough to initiate a redistributive trend.

Furthermore, the Commission has released a number of reports containing data of a general nature, which makes it arduous to determine which actions, be they national or European, are likely to have more impact on economically and socially challenged territories. As a matter of fact the latest reports on Cohesion Policy, besides being released at a slower pace, have been much more critical of the situation than their earlier counterparts. They no longer limit themselves to listing out the many miles of motorway or water treatment plants built, they also set such undertakings against the background of the respective significance of national cohesion policies in Europe.

Lastly, the use of citizen assessment or qualitative data in analysing the impact of the policy is still incipient. Most works devoted to Regional Policy (the latest to date being that of Marjorie Joue ${ }^{10}$ ), have adopted a defined economic, legal or historical approach, and the space reserved for citizens is reduced ${ }^{11}$. For instance, there is no broad assessment of the "class of participants" signing up for PRE (T.N. Academic Achievement Programme) in the territories said to be "economically and socially challenged" or "lagging in development". Any qualitative analysis is quite often missing. Yet M. Jouen wrote as a conclusion to her work: "an ambitious bid, crowned with success, is still the safest means of restoring the confidence of Europeans in

\footnotetext{
${ }^{9}$ As an example, see the objectives stated by the European Commission for Europe 2020 : http://ec.europa.eu/europe2020/europe-2020-in-a-nutshell/priorities/inclusive-growth/index_fr.htm

${ }^{10}$ JOUEN M. - La politique européenne de cohésion. Paris : La documentation française, 2011.

${ }^{11}$ See also GAUBERT, N. - Le démarrage d'une politique de cohésion sur des bases renouvelées, Pouvoirs locaux, $\mathrm{n}^{\circ} 98$ III-2013, pp. 83-87.
} 
Europe" ${ }^{\prime 2}$. A search by iteration would quite probably reveal that the final sentence is one of the few passages containing a reference to Europeans and to citizenship, as the book dwells at great depth on the complex legal workings of Regional Policy.

\section{II - Lack of readability and the European citizen. A policy reserved for the privileged insiders?}

The standing of Regional Policy is difficult to define given the non-federal nature of the European project. As an action undertaken by the EU, the latter dictates that it is to be implemented through the principles of subsidiarity and additionally.

It is both an ascending and a descending procedure. During the initial stages, while programmes are being put in place, the procedure is highly centralised, concerning heads of States and of governments, the European Commission and the Parliament. Even though electronic opinion sampling techniques ${ }^{13}$ make it possible, in theory, to consult the actors of such policy, it has to be said that the numbers of those willing to take part remain low, most of the participants being the actors most directly involved and having the greatest decisional power, starting with the associations of elected representatives and other lobbies. In France, the implementation of operational programmes (OP) then becomes the competence of the DATAR (T.N. Delegation for Regional Planning and Regional Attractiveness) and the Regions. Only subsequently are project carriers called to submit their applications to the schedule. Thus the stake is not, truly speaking, regional development, as the starting point of the regional implementation of the policy is not concerned with the needs of the territories: the Commission allocates the designated amounts to the States, the States to the Regions and only then are the Regions required to explain how they intend to spend the budget allocated to them. The rigidity of this cascading logic is somewhat mitigated by the fact that territorial dynamics is required for the emergence of projects. Where it is lacking, the consumption of allocated funds remains very limited. The rallying of local energies therefore guarantees the consumption of funds, an essential cog in the logic of Regional Policy.

\footnotetext{
${ }^{12}$ JOUEN, Marjorie, op. cit., p. 174.

${ }^{13}$ Link to the consultation website:

http://ec.europa.eu/regional_policy/archive/consultation/terco/consultation_fr.htm
} 
Even though the European Commission and DATAR in France strive to expose the logic and the functioning of Regional Policy, its access remains reserved for certain insiders. To Colomba Dussart, special advisor on Europe for the SGAR (T.N. General Secretary of Regional Affairs) at the regional préfecture of Midi-Pyrénées "such scant citizen knowledge stems from being prejudiced against a complex entity which is above the States. When entering the process of applying for subsidies, it must be acknowledged that a certain amount of faith is needed, to face, as a project carrier, the complexity of the arrangement, understand the channels for reporting progress and bear with the length of the procedures" ${ }^{\prime 1}$. In reality the outcome hinges wholly on the efforts made at the regional level in order to facilitate the articulation of the project and discourage any elitism among citizens, thus enabling well-informed actors to respond to the oftentimes complex, multiple requirements of project articulation (pursuing additionality of funds, implementing the assessment procedure etc.) and having done so, to gain access to the said programmes. It suffices to peruse the DATAR ${ }^{15}$ notes to measure the degree of technicality of that procedure and the overuse of unfriendly jargon and less-than explicit acronyms. Pascal Chazaud, a consultant with the public consulting group "Europe et territoires conseil", says such complexity and technicality tend to discourage project carriers, sometimes even a posteriori, when they "are left wondering, once the operation has been carried out, if the outcome was really worth devoting such energy to addressing the administrative and financial aspects of the project" $" 16$. It is, therefore, obvious that this policy should be transposed into comprehensible terms and explained to any citizens who may eventually submit an application. Gérard Onesta explains that the website l'Europe en Midi-Pyrénées ${ }^{17}$ was designed with that aim in mind, and that it has been recognised as the most user-friendly among those existing throughout the various French regions.

\footnotetext{
${ }^{14}$ Interview with Colomba Dussart and Pascale Jové on 7 January 2014 at the Préfecture de Région Midi-Pyrénées.

${ }^{15}$ Territoires en mouvement $\mathrm{n}^{\circ} 12$, automne 2013, p. 8.

${ }^{16}$ Interview with Pascal Chazaud on 5 December 2013.

${ }^{17} \mathrm{http}: / / \mathrm{www}$.europe-en-midipyrenees.eu/
} 


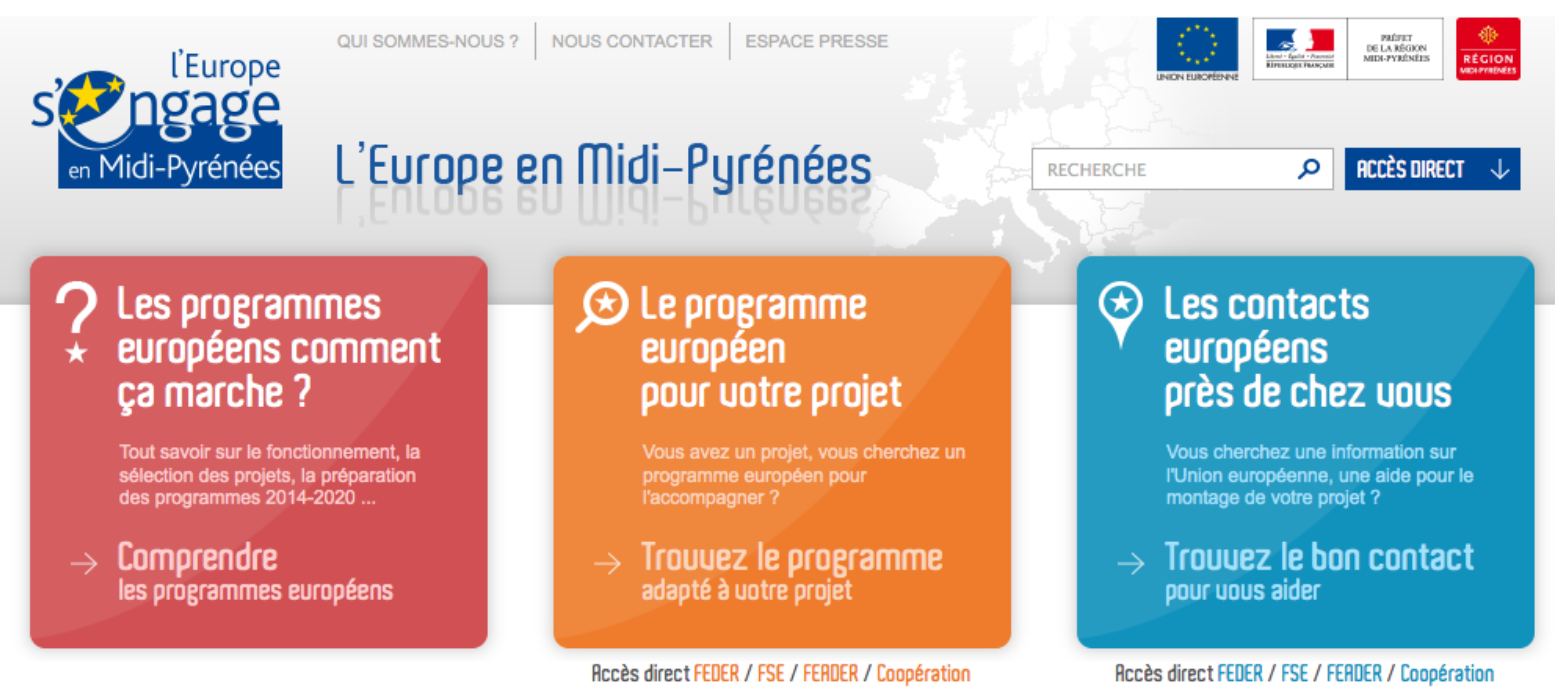

Photo: Homepage of the website «L'Europe en Midi-Pyrénées » $\left(\right.$ April 2014) ${ }^{18}$.

This method for teaching the skills of politics highlights several key elements for success, namely the presence of relaying operators, of intercessors capable of decoding the inner workings of Regional Policy and of providing assistance regarding the articulation of projects. Such commitment to transparency is praiseworthy as, in the past, many authors have underlined a burdensome screening process at a national level, and other types of filters of such nature as to circumscribe the impact of European funds: the co-financing of projects, the concept of additionality all too often made it possible for elected representatives to conceal the inflow of funds from the EU and divert the latter to municipal, regional or departmental appropriation funds. Overly powerful local public figures hoarded the knowledge of the European financing and Regional Policy apparatus, in a bid to keep control of that particular project-financing channel. That era is now largely obsolete, and it seems fair to think that since 1989 successive programmes have facilitated access to European funding. However, the existing devices are still in dire need of decoding, and programmes can only be made available to the general public through the work of skilled territorial intercessors. In an article published in the online magazine Acteurs publics Valérie Segon, while describing the new 2014-2020 programme schedule,

\footnotetext{
${ }^{18}$ Left frame: "How do European programmes work? Everything on the functioning and the selection of projects, the preparation of the 2014-2010 programmes... Understanding European programmes."

Center frame: "The European programme that is right for your project. Do you have a project? Are you seeking a European programme to bring it to fruition? Find the programme for your project"

Right frame: "European contacts near you. Do you need information on the European Union? Are you seeking assistance to articulate your project? Find the right contact."
} 
explained why certain business leaders experience a sense of dismay when considering the subsidies available within the framework of Cohesion Policy: "all they need to do is wrap up their project neatly and make it attractive and marketable, so that it fits the image requirements of Europe 2020. For that purpose, they will easily get assistance from seasoned experts and a slew of former business bankers and consultants who have specialised in the hunt for European funds"19.

Ultimately it is difficult to ascertain who the main beneficiaries of those programmes are, although the numbers of citizens acting independently as project carriers are quite often much less significant than those of public organisations: ICC, local authorities etc. On the other hand certain instruments of Cohesion Policy, when designed to serve a specific group of professionals, have proved quite popular among local actors: the LEADER programmes (now part of the CAP) and the INTERREG programmes seem particularly relevant in that respect. The former (i.e. LEADER), has introduced new methods for articulating projects, its main goal being to foster territorial development; it includes citizens' associations involved in territorial projects, the decentralised management of appropriations, final project assessment etc.

To citizens, the projects co-financed by Europe that have come to fruition remain scarcely visible, notably due to the absence, locally, of European representatives who may highlight the contributions made by Europe, for instance on the occasion of inaugurations during which project carriers enjoy media exposure (i.e.: Conseil Général, Conseil Régional... * T.N. Departmental Council, Regional Council).

Few studies exist on the impact of Regional Policy on European citizens. Only three Eurobarometers ${ }^{20}$ Flash opinion surveys were carried out on the subject in 2008, 2010 and 2013. They concern the knowledge and perception that European citizens have of Cohesion Policy. The same questions were asked in the three surveys:

- Are Europeans aware of the subsidies granted within the framework of the European Cohesion Policy?

- Do they feel that their town / city or region has benefitted from such subsidies?

\footnotetext{
${ }^{19}$ SEGOND, Valérie - "Les fonds européens seront mieux fléchés", acteurs publics.com, 18 février 2014.

${ }^{20}$ Created in 1973 by the European Commission, Eurobarometer is a valuable measuring tool for researchers concerned with European issues. The analysis of public opinion is carried out by means of polls relying on questionnaires distributed to at least one thousand people in each member state. Eurobarometer "flash surveys" are carried out by phone only.
} 
- Do Europeans agree with the notion that European Cohesion Policy should be focused on helping the poorer regions catch up with the richest ones?

- Do they agree with the subsidiarity principle?

- What should the current and future priorities of European Cohesion Policy be?

Nearly 27000 citizens over 15 years of age and residing in 27 member States of the European Union were polled by telephone ${ }^{21}$. It was surprising to observe a decrease in the visibility rate of Regional Policy: $34 \%$ of European citizens claimed to be aware of any projects co-financed by the EU in their regions in 2013, down from $49 \%$ in 2008, or one-third instead of half of those polled. Such rate is even lower in France, with $28 \%$ of French citizens being aware of any projects co-financed by Europe. However, these results are complemented by another figure regarding a rise in positive opinions: more and more European citizens - from among the minority aware of the facts - believe that EU support has had a positive impact on the development of their regions (77\% in 2013 up from $70 \%$ in 2008). On the other hand, $8 \%$ of the citizens polled saw no positive impact from European subsidies granted within the framework of the Cohesion Policy, and 9\% even perceived a negative impact.

Although this assessment is on the whole positive, European citizens do not feel that those projects enhance their daily lives in any way (75\% of European and $91 \%$ of French citizens polled). When considering the results on a country-by-country basis it emerges, unsurprisingly, that the countries where citizens are better informed of the existence of the Cohesion Policy are precisely those countries which benefit from it the most (those having the greatest number of regions with converging challenges as per the map ${ }^{22}$ ). In those States, an average of 60 to $70 \%$ of citizens have heard of EU co-financing, or a 30 to 40 point-increase from the European average.

Being mindful of the gap between the beneficial role of Cohesion Policy and its perception by European citizens, the European Commission is seeking innovative mediums and tools to make the public aware of its nature. In March 2014, it published a document featuring six short comic strips by various authors ${ }^{23}$ in order to highlight the diversity of the projects achieved with the support of European Cohesion Policy funding, and their actual impact on the daily lives of

\footnotetext{
${ }^{21}$ And over 28000 citizens in the 28 member States for the latest poll following the adhesion of Croatia.

${ }^{22}$ The map of eligibility for the 2014-2020 Cohesion Policy can be viewed on the European Commission website : http://ec.europa.eu/regional_policy/what/future/eligibility/index_fr.cfm

${ }^{23}$ The comic strip can be downloaded freely on the website: http://bookshop.europa.eu/fr/partenaires-pbKN0414052/
} 
European citizens from different countries. The objective is to provide a detailed description of the projects achieved with the support of Europe. One may, however, question the efficiency of the distribution of such material and the relevance of targeting a public of upper-secondary school students, as it seems. The stories told are rather naive and the medium appears to be poorly designed considering their intended purpose.

Above and beyond any misgivings spurred by the lack of knowledge or lack of readability of Cohesion Policy, it must be acknowledged that the said policy is plagued with structural blockings resulting from the very nature of the European project, raising questions that run much deeper than the mere framework of Cohesion Policy. Budget is one example. In 1989 the allocation for European Regional Policy was 10 billion euros, rising to 54 billion euros in 2013, or one-third of the European budget. The sharp increase reflects the significance of such policy in building unity across the EU, and clearly shows that heads of States and of governments have made it their priority. Yet, the European budget represents less than $1 \%$ of the wealth of the concerned States, and the openly-stated ambition to promote solidarity across the European Union remains limited. Solidarity and convergence transit through a series of other geographic stages (there is a national, a regional, a departmental, an inter-municipal and a municipal... stage). In its reports on Cohesion Policy, the European Commission recalled that "solidarity in the Union begins at home", and primarily with existing national solidarity instruments which redistribute nearly $50 \%$ of State GDP in a context dominated by welfare States $^{24}$.

Similarly, Europe's money is but the result of the redistribution of the money pooled by States, since there is no specific European tax, and therefore no resources specifically allocated to the European project. Thus States often vie for favourable rates of return and strive to weigh in on discussions involving the European budget, a tendency which has sometimes been termed the "poison of fair return" 25 . To Gérard Onesta, this is a fundamental stumbling block in the EU, and it must elicit citizen concerns: "So long as we do not set up a resource system with funds specifically devoted to Europe, one which may de-nationalise the money pooled, it won't work, because each State is adding up numbers and going for the least-constraining option, petty as this

\footnotetext{
${ }^{24}$ This was clearly explained by Laurent Davezies in his work, La République et ses territoires. La circulation invisible des richesses, Seuil, coll. «La république des idées », 2008.

${ }^{25}$ LE CACHEUX, J. ; LAMY P. - Budget européen : le poison du juste retour. S.1. : Fondation Notre Europe, novembre 2005.
} 
may be, and none seems to acknowledge that the money pooled creates synergy and makes it possible to reduce the scale of the spending. Resources must be denationalized, any undesirable occurrence - pollution, speculation, uncontrolled exploitation - must be taxed, and any activity we may wish to promote, such as work, should see its tax burden reduced or nullified"26. This of course would require a complete overhaul of the European budget.

The impact of Cohesion Policy on European citizens is, therefore, difficult to assess since such instrument is but one among several shaping factors and the scope of its influence on the European project is not easily identifiable in the current context.

\section{III - The deepening of inequalities within the EU. Could Cohesion Policy be instrumental in reducing such gaps?}

In the context of a major crisis affecting Europe, it may seem reasonable to think of Cohesion Policy as the best tool for addressing the dysfunctions of society and the economy. Such instrument should appeal to European citizens as it is tangible, being based on projects aimed at transforming territories for the better and making residents' lives easier.

Cohesion Policy was devised and implemented when significant disparities among territories emerged as a result of the 1975 crisis, and it was reinforced with the adhesion of new member States lagging behind in development. It was a response intended to reduce territorial gaps since territorial and social inequalities had deepened due to EU expansion to the East and also to the polarising effects of globalisation. Pierre Veltz ${ }^{27}$, as early as 1996, was heralding in a world of interconnected archipelagos, with great metropolises paying little or no attention to neglected hinterlands with few connections to the main flux of people and technology.

The magnitude of those two stakes elicited a twin response from the EU on the basis of existing territorial development policies:

- on the one hand, to foster competitiveness and to reinforce the presence of large cities within the context of globalisation, by supporting and promoting excellence and state-of-the-art, innovative technologies etc.;

\footnotetext{
${ }^{26}$ Interview with Gérard Onesta, op. cit.

${ }^{27}$ VELTZ, Pierre - Mondialisation, villes et territoires. Paris : PUF, 1996.
} 
- on the other hand, to lessen the impact of territorial inequalities by reducing development gaps among individuals (social inclusion) et territories (cohesion).

The said objectives collided with the intrinsic contradictions of the model thus defined. How is it possible to address issues of competitiveness, as was the case with the Lisbon Council in 2000, and of cohesion? ${ }^{28}$ It soon became obvious that Europe is setting goals for growth and excellence in a bid to emerge as the world's most powerful knowledge-based economy as the Lisbon Council proclaimed in 2000. In fact, Cohesion Policy is perceived as a mere auxiliary device to mitigate the effects of a model favouring the most dynamic territories and the most innovative sectors of the industry, etc.

There is a hard-to-solve contradiction inherent in the dual rhetoric promoting competitiveness and solidarity, with the ensuing necessity to make choices in favour of one or the other. Thus the 2007-2013 Cohesion Policy programme displayed "areas of competitiveness" and other areas lagging far behind, reflecting accurately enough the oxymoronic European slogan, "United in diversity".

The lack of efficiency in addressing matters of solidarity may also stem partly from the primary field for Regional Policy intervention: the region, or rather a NTUS 2-type unit. That statistical division was adapted to the European scale and is now the key grid to collect development indicators, among which GDP ranks first. However, that such statistical approach is the most adapted to assess the stakes of territorial cohesion is anything but certain. Statistical images may be distorted when certain regions are buoyed up by the wealth of their metropolis, yet suffer significant infra-regional disparities. Classification into broad types of areas prevents a more subtle territorial differentiation. For instance: Toulouse, a dynamic metropolis with an economically-challenged hinterland ${ }^{29}$ or Prague, which ranked first among European Regions as per its GDP, concealing the weakened situation of the Czech hinterland.

\footnotetext{
28 "In effect, while the approach intended to make sectorial politics coherent (assessment of the political coherence of Europe) and the approach involving a "green and clean" Europe (which stems from Göteborg's strategy) could seem to be complementary, the approach concerning European stability (balancing inequalities among European territories) and that concerning competitiveness in Europe clearly diverge.”, in Bernard Elissalde, Frédéric Santamaria, Philippe Jeanne, "L'affirmation du rôle de la Commission européenne : de l'importance du discours sur la cohésion”, L'Espace Géographique, Belin, 2013-2, p. 99.

${ }^{29}$ The Conseil Régional de Midi-Pyrénées edited a leaflet called «L'Exception Midi-Pyrénéenne» in May 2013 in order to describe the situation in a region where a hypertrophied regional metropolis - the Toulouse urban area lies side by side with a vast, sparsely populated landlocked territory, which is concealed by the Toulouse metropolis. The region called for « a satisfactory response from European and national public authorities in the name of perequation $»($ p. 4).
} 
The method chosen to amend disparities also carries contradiction. The European Commission is torn by the need to satisfy two requirements: on the one hand, to facilitate the consumption of European funds and, on the other hand, to preserve solidarity among its territories. Yet, more often than not, the territories most in need of European financing are not the most dynamic in terms of funds consumption. This finds an explanation in the concept of eligibility, which requires the speedy articulation of projects by skilled and efficient regional and infra-regional administrations with perfect understanding of the inner workings of the application process, the channels to be used and the competent authorities. However, in weakened territories local actors cannot avail themselves of a network of operators able to formalise needs through applications. The European Commission has observed that in countries having recently joined the Union, metropolises are much more dynamic with regard to funds consumption than the other territories are. It is a fact that any objective set towards quick funds consumption shall automatically entail the concentration of available funds on metropolises, in the hope to witness the effects of the economic theory of François Perroux. On the contrary, the practice of privileging support to territories other than metropolises often makes it possible to address needs that are dire but difficult to formalise, and thus require a longer-lasting scheme of such a nature as to eventually hamper the overall rate of funds consumption.

How to escape such contradiction? And how can this instrument best address tense economic and social situations across the Union? Back in the late 1980s Roger Brunet identified a continuance of economic and social trends between European regions overlapping two or more States. The European Commission incorporated his work into a 1994 study called "Europe 2000+". The Commission advocated for the taking into consideration of European macro-regions overlapping State borders and sharing not only common features but also development stakes. The fruit of such work was hoped to avoid an over-simplification of the European regionalpolicy zoning which may have resulted in large artificial systems lacking relevance at many levels. To the contrary, having devised such macro-regions, Europe was endowing itself with a truly European distribution of territories sharing stakes and requiring tailored policies. However, heads of States and of governments very quickly rejected such innovation as they considered it to infringe the territorial limits of States. As a matter of fact, the above-described vision of territorial distribution is in the transnational section of the INTERREG programmes. Although the method involved entails a risk of enhancing regional entities, at least it embraces the reality 
of the territories. In the new 2014-2020 programme schedule, a choice was made to target themes (energy or innovation for instance) rather than territories. There is a risk of voiding Cohesion Policy of its substance, being as it is more reliant on European choices to be orchestrated on a regional and infra-regional scale, than on integrated territorial programmes.

In the new programme schedule, access to European funds appears to be more and more difficult for small structures such as community associations, due not only to the increased complexity of the application and follow-up procedures now requiring the assistance of consultancy firms or engineers specialised in establishing eligibility for costly projects ${ }^{30}$, but due also to the growing reluctance of States and local authorities to put together applications for limited funds. Pascale Jové, deputy advisor on European programmes with the Préfecture of the Région Midi-Pyrénées, has expressed her pessimism concerning future individual request for European funds emanating from citizens or small community associations: "Can you picture the complexity and the processing cost for a subsidy of a mere $2000 €$ ? What may well happen in the future is, the whole thing is such a drag that no one will even consider applications for 2000 or $3000 €$. Now we're hearing that regions don't want to go to the trouble the State goes to as far as processing is concerned, and they'll only retain applications concerning subsidies over a given ceiling. We'll be getting more of the significant applications and the opportunities available to citizens will be fewer." ${ }^{31}$ Faced with the increased professionalization of the procedure for accessing European funds, which contributes de facto to alienating grassroots citizens from Europe, the EU may be well inspired to use part of the funding allocated to its Cohesion Policy to finance modest projects emanating from smaller structures. Targeted microfinancings not requiring additional co-financing would make it possible for citizens to identify the funds as European funds, much as occurs with the Erasmus university exchange programmes. Students going to other European countries to study are clearly aware that that opportunity is provided by Europe, while the "lever effect" of Cohesion Policy is masked by the contributions of cofinancing partners.

\footnotetext{
30 "It is becoming increasingly hard for typical commmunity associations or European citizens to avail themselves of European financings as the procedure now requires the assistance of an engineer specialised in establishing project eligibility. Yet, up until 2006, associations were the prime beneficiaries of those European funds". Interview on 18 December 2013 with Gaëlle Covo, project engineer and special advisor for research with the cellule Europe at Université de Toulouse-Capitole.

${ }^{31}$ Interview with Colomba Dussart and Pascale Jové, op. cit.
} 


\section{Conclusion}

As a sense of doubt is pervading Europe, Regional Policy should be that which citizens appreciate and avail themselves of the most as its intended goal is cohesion through inclusion. Yet it is not so, and there are several reasons for this:

- the small volume of financings with respect to the national policies of welfare States;

- $\quad$ poor knowledge of the rules for using funds;

- the complexity of project articulation, the control and assessment of running projects;

- pledge to solidarity paired with a commitment to competitiveness;

- the principle of additionality which blurs the lines of European intervention and makes it undistinguishable from national and infra-national policies.

The persistence and in some cases the deepening of territorial inequalities among and between EU member States, clearly has had a role to play in the mistrust, the lack of interest or the rejection of Europe by its citizens. The effects of the Single Market and the competition policy based on competitiveness are no doubt stronger than the impact of Cohesion Policy and socio-economic solidarity. Reversing the trend would require a significant increase of the budget allocated to Cohesion Policy, but in the context of the successive financial and monetary crises which have been affecting Europe since 2008, the States have clearly decided against such measure and have reduced the EU's financial means, while still requiring greater efficiency from Cohesion Policy. Any solidarity experienced by citizens is likely to remain a prerogative of the State, to be exercised on an infra-national territory to the detriment of the EU and the European territory. Should this be deplored? It is a different debate which leads back to the very nature of the European project, as do all European public policy matters.

\section{Bibliography}

BIANCARELLI, F. ; GRENSON O.; RAFFAELE S.; SPELTENS O.; TENG P.; YOU, Miel R. - Partenaires. Bruxelles: Commission européenne, Direction générale pour la politique régionale et urbaine, 2014, $75 \mathrm{p}$. 
COURCELLE T.; Taulelle F. - "La politique de cohésion, un instrument de la citoyenneté?" In. CLEMENT-WILTZ L., POILLOT-PERUZZETTO, S. (dir.) - Construire la citoyenneté européenne. Bruxelles : P.I.E. Peter Lang, 2014, pp. 107 à 124.

DAVEZIES L. - La République et ses territoires. La circulation invisible des richesses, coll. « La république des idées ». Paris : Seuil, 2008, 109 p.

DREVET J.-F. - Histoire de la politique régionale de l'Union européenne. Paris : Belin, 2008, $285 \mathrm{p}$.

ELISSALDE B. ; SANTAMARIA F. ; JEANNE P. - "L'affirmation du rôle de la Commission européenne : de l'importance du discours sur la cohésion." In L'Espace Géographique. Paris : Belin, 2013-2, pp. 97 à 114.

JOUEN M. - La politique européenne de cohésion. Paris : La documentation française, 2011, $188 \mathrm{p}$.

LE CACHEUX, J.; LAMY P. - Budget européen : le poison du juste retour. S.1. : Fondation Notre Europe, novembre 2005, $51 \mathrm{p}$.

VELTZ, P. - Mondialisation, villes et territoires. Paris : PUF, 1996, 288 p. 